Uluslararası Sosyal Bilgilerde Yeni Yaklaşımlar Dergisi, 2021, 5(1), 119-134

International Journal of New Approaches in Social Studies, 2021, 5(1), 119-134

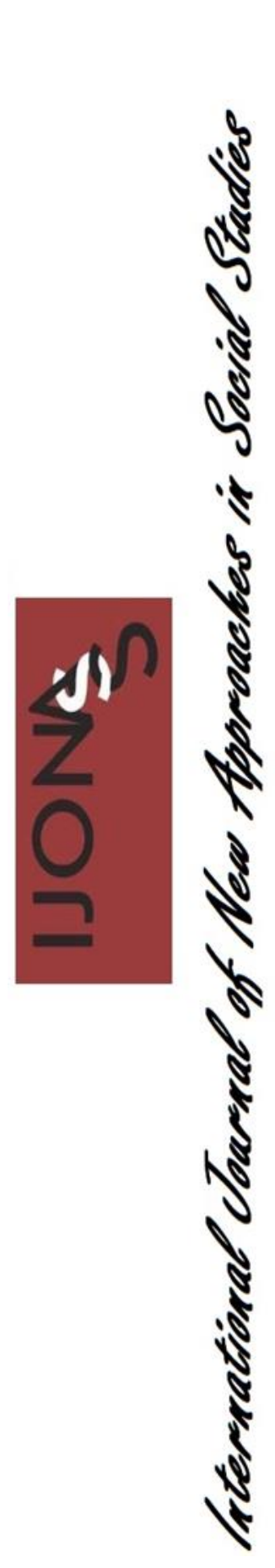

\title{
Okuma Güçlüğü Yaşayan İlkokul Öğrencilerinin Okuma Hatalarının İncelenmesi
}

\author{
Ayşegül AVŞAR TUNCAY ${ }^{*}(\mathbb{D})$ \\ Gönderilme Tarihi: 31 Ocak $2021 \quad$ Kabul Tarihi: 21 Mayı 2021 \\ DOI: $10.38015 /$ sbyy. 871718
}

\begin{abstract}
$\ddot{O}_{z:}$
Okuma güçlügü, normal veya üstün zekâ düzeyinde olmasına rağmen öğrencinin okuma becerilerinde problem yaşamasına sebep olan özel öğrenme güçlüğüdür. Öğrenciyi okuma-yazma sürecinde olumsuz etkileyen birçok faktör mevcuttur ve bunlardan bir tanesi de okuma esnasında yapılan sesli okuma hatalarıdır. Bu araştırmada okuma güçlüğü yaşayan ilkokul ögrencilerinin sesli okuma sırasında yaptıkları okuma hataları çeşitli değişkenler açısından belirlenmeye çalışılmıştır. Çalışma, nicel araştırma yöntemlerinden betimsel tarama modeli kullanılarak yapılmıştır. Veriler, uygun örnekleme yöntemi ile belirlenen 2019-2020 ĕgitim-ögrretim yllında Mersin ili merkezinde ilkokul 4. sınıfa giden toplamda 32 ögrenciden elde edilmiştir. Öğrencilerin sesli okuma sırasında yaptıkları hatalar ve bu hataları hangi sıklıkta yaptıklarl; cinsiyet, anne ve baba eğitim seviyesi, kitap okuma sıklıklarl, tercih ettikleri kitap türü ve okuma ortamına göre farklılaşıp farklılaşmadiğı belirlenmiştir. Buna göre en çok yapılan sesli okuma hataları ekleme yapma, çıkarma yapma ve yerine koymadır. Bunun yanında demografik özelliklerin okuma güçlügü yaşayan ilkokul ögrencilerinin yaptıkları okuma hataları üzerinde farklılık yaratmadĭ̆g sonucuna ulaşılmıştır. Dolayısıyla araştırma sonucunda sesli okuma hatalarında demografik özelliklerin belirgin bir hatanın öne çıkmasında etkili olmadığı, hataların sıklıklarının farklı seviyelerde olduğu söylenebilir.
\end{abstract}

Anahtar Kelimeler: İlkokul ögrencileri, okuma güçlüğü, okuma hataları.

\begin{abstract}
:
Reading difficulty is a learning disability that causes issues in the reading skills of a student even though they may be at a normal or gifted level. Many factors can negatively affect a student's literacy process, and one of these factors is errors made while reading aloud. The present study aims to determine the errors that primary school students with reading difficulties make while reading aloud according to various variables. The study employs the descriptive survey model, which is a quantitative research method. The data was obtained from 32 fourth-grade students in the Mersin city center in the 2019-2020 academic year. The sample was obtained with the appropriate sampling method. The study examines the errors made by the students while reading aloud and how often they made these errors, and whether these errors differed according to the students' gender, parents' education level, frequency of reading, preferred reading material, and reading environment. The most common reading errors were found to be insertion, subtraction, and substitution. Furthermore, the study found that demographic characteristics did not influence the reading errors made by primary school students with reading difficulties. Therefore, the study revealed that demographic factors do not influence the prominence of a certain error, and the frequency of the errors differs.
\end{abstract}

Keywords: Primary school students, reading difficulty, reading errors

\footnotetext{
${ }^{1}$ Mersin Üniversitesi, Türkiye. Orcid ID: 0000-0002-0520-1747

*** SorumluYazar (Corresponding Author): aysegulaat@mersin.edu.tr
} 


\section{GíRIŞ}

Zihin gelişimine en büyük katkı sağlayan öğrenme alanlarının başında okuma gelir. Çünkü ilk kullanılan öğrenme becerisi olan dinlemeden sonra okuma, en önemli bilgi edinme, bilgi dağarcığını geliştirme yollarından biridir (Karatay, 2013). Akyol'a (2013) göre, "İnsana ait temel özelliklerden biri olan okuma, sihirli bir süreçtir ve birçok unsur tarafından etkilenir. Okuma, insanın yeni kelimeler öğrenerek, anlayışlar kazanarak, hayaller oluşturarak, yaratıcılığını geliştirerek ufkunu genişletir ve derinleştirir". Sever'e (2011) göre, "Okuma; sözcüklerin, duyu organları yoluyla algılanıp anlamlandırılmasına, kavranmasına ve yorumlanmasına dayanan zihinsel bir etkinliktir”. Çocuklar okumayı öğrenirken önce sesleri öğrenirler. Daha sonra yazılı kelimeleri tanımak için seslerle harfler arasında bağlantı kurmayı öğrenirler. Yeterince okuma çalışmaları ve sık tekrarlar yapılırsa kelimeyi bir bütün olarak görmeye başlarlar. Dolayısıyla kelimeler bir süre sonra otomatik olarak tanınmaya başlar ve okuma ile eş zamanlı olarak düşünceler gelişmeye başlar. Çocuk bu sayede okuduğu metni anlayabilir (Doğangün, 2008).

İlkokul birinci ve ikinci sınıfta kelime tanıma ve akıcı okumaya odaklanan çocuk, üçüncü ve dördüncü sınıfta okuduğu metni anlamaya çalışmaktadır. Birinci ve ikinci sınıfta kelime tanıma evresinde zorlanan çocuktan okuduğunu anlamasını beklemek biraz zorlayıcı olmaktadır. $\mathrm{Bu}$ nedenle çocuk okumadan kaçma, okurken kelime, hece, satır atlama, aynı kelimeyi tekrar okuma, yazılanın yerine başka bir kelime okuma, sesleri karıştırma, yavaş okuma ve dolayısıyla okuduğunu anlayamama gibi güçlükler yaşamaktadır (Daly, Chafouleas \& Skinner, 2005; Smart, Prior, Sanson \& Oberklaid, 2001).

Okuma güçlügüu, normal veya üstün zekâ düzeyinde olmasına rağmen öğrencinin okuma becerilerinde problem yaşamasına sebep olan özel öğrenme güçlügüdür. Okuma güçlüğü yaşayan çocukların okudukları metinde geçen bir kelimeyi tanıyamamaları yanlış okumalarına ve yanlış anlamalarına sebep olmaktadır (Akyol \& Ketenoğlu Kayabaşı, 2018). Dolayısıyla zayıf okuma düzeyine sahip olan bu çocukları okuma-yazma sürecinde olumsuz etkileyen birçok faktör mevcuttur ve bunlardan bir tanesi de okuma esnasında yapılan sesli okuma hatalarıdır. Okuma güçlüğ̈̈ yaşayan çocukların en fazla yaptıkları okuma hataları; ekleme yapma, kelimeleri atlama, yerine koyma, tekrar etme, yanlış okuma, tersinden okuma ve noktalama işaretlerine dikkat etmeden okuma şeklinde sıralanmaktadır (Akyol, 2012; Sidekli, 2010). Okuma güçlüğü yaşayan çocukların yaptıkları okuma hataları ve nedenleri Akyol (2012) tarafından şu şekilde açıklanmıştır:

Tersine çevirme (yerine koyma); ilkokul birinci sınıf çocukları arasında en çok görülen hatalardan biri "ters çevirme" hatasıdır. Sesleri (b yerine d veya d yerine b gibi) ya da kelimeleri ters okumalarından kaynaklanan bu hata genellikle ilk okuma-yazmayı öğrenirken belirir. Eğer ileriki yaşlarda da devam edildiği görülürse sorunun çözüme ulaşması sağlanmalıdır (Yüksel, 2010). Ekleme veya çıkarma yapma hem ekleme yapma da hem de çıkarma yapmada çocuk ya çok hızlı okuduğu için bu hatayı yapıyordur ya da dikkat problemi vardır. Bu durum söz konusuysa eğer okuma sonunda çocuğun hata yaptığı kelimeler tekrar okutulmalıdır. Tekrarlama (geri dönme); tekrar hatalarının kelime tanımanın yetersizliğinden kaynaklandığ söylenmektedir. Çocuk yeteri kadar kelime tanıma becerisine sahip olmadığ 1 için zaman kazanmak istemekte ve gereksiz kelime tekrarına düşmektedir. Çocuğun çok tekrar yaptığ görülürse kendi seviyesinden bir alt seviyede okuma metni okutulmalıdır. Yanlış telaffuz; okuma güçlügü yaşayan çocuğun okurken kelimenin ilk harfine ya da ikinci harfine bakarak 
geri kalan diğer seslere dikkat etmeden kelimenin devamını tahmin etmesi gibi hatalardır. Duraklama; okuma güçlüğü yaşayan çocuğun kelimeyi okurken en az iki saniye beklemesi, kelimeyi tanımada zorlanması gibi hatalardır. Kelimeyi tanıması için sık tekrar yapılması gerekmektedir. Yanlış okuma; okuma güçlüğü yaşayan çocuğun kelimeyi tamamen başka bir kelime gibi seslendirmesiyle oluşan hatadır. Metinde geçen "bugün" kelimesini "bir gün" gibi okuması bu hataya örnek olarak gösterilebilir. Ülkemizde okuma hataları ile ilgili yapılan çalışmalara bakıldığında genelde ilkokul seviyesinde okuma güçlüğü yaşayan öğrencilerin okuma düzeylerini geliştirmeye yönelik yapılan çalışmalar olduğu görülmektedir (Akyol \& Ketenoğlu Kayabaş1, 2018; Akyol \& Kodan, 2016; Akyol \& Sever, 2019; Dağ, 2010; Keskin \& Baştuğ, 2013; Kuruoğlu \& Şen, 2018; Yangın \& Sidekli, 2006; Yıldırım, Turan \& Bebek, 2012). Okuma güçlüğü yaşayan ortaokul kademesindeki çocukların okuma hatalarının çeşitli değişkenler açısından incelenmesi Bilge ve Sağır (2017) tarafından yapılmış fakat ilkokul kademesinde böyle bir çalışmaya rastlanmamıştır. Bu çalışma ilkokulda okuma güçlüğü yaşayan çocukların okuma sırasında yaptığı hatalar ve bunların çeşitli değişkenler açısından incelenmesini araştırmaktadır. Araştırma, bundan sonraki çalışmalarda okuma güçlüğü yaşayan çocukların okuma hatalarının belirlenmesinin farklı değişkenler açısından tespit edilmesi bakımından değerli ve önemlidir.

\section{Araştırmanın Amacı}

Bu çalışma, okuma güçlüğü yaşayan ilkokul dördüncü sınıf öğrencilerinin sesli okuma sırasında yaptıkları okuma hatalarının çeşitli değişkenler açısından farklılık gösterip göstermediğini belirlemek amacıyla yapılmıştır. Araştırmada; okuma güçlüğü yaşayan ilkokul öğrencilerinin sesli okuma sırasında yaptıkları okuma hataları çeşitli değişkenlere (cinsiyetleri, en çok tercih ettikleri okuma ortamı, anne ve baba eğitim seviyesi, kitap okuma sıklıkları ve tercih ettikleri kitap türü) göre farklılık göstermekte midir? sorusuna yanıt aranmaktadır.

\section{YÖNTEM}

$\mathrm{Bu}$ araştırmada okuma güçlüğü yaşayan ilkokul dördüncü sınıf öğrencilerinin sesli okuma sırasında yaptıkları okuma hatalarının çeşitli değişkenler açısından farklılık gösterip göstermediği belirlenmeye çalışılmıştır. Çalışma, nicel araştırma yöntemlerinden betimsel tarama modeli kullanılarak yapılmıştır. Betimsel tarama, bir durum ya da olaya ilişkin katılımcıların görüşlerinin veya ilgi, yetenek, tutum vb. özelliklerinin belirlendiği çalışmalar olarak tanımlamaktadır (Büyüköztürk, Kılıç Çakmak, Akgün, Karadeniz \& Demirel, 2016; Creswell \& Creswell, 2018; Patton, 2002). Tarama araştırmalarının temel amacı mevcut durumu betimlemektir (Keser Özmantar, 2019).

\section{Çalışma Grubu}

Çalışma grubu, amaçlı örnekleme yöntemlerinden uygun örnekleme yöntemiyle seçilmiş ilkokul öğrencilerinden oluşmaktadır. Veriler, 2019-2020 eğitim-öğretim yılında Mersin il merkezindeki 18 ilkokulda dördüncü sınıfa giden toplamda 32 öğrenciden elde edilmiştir. Çalışma grubuna ait demografik özellikler Tablo 1'de sunulmuştur. 
Tablo 1. Öğrencilerin Demografik Özellikleri

\begin{tabular}{|c|c|c|c|c|c|c|c|}
\hline $\begin{array}{l}\text { Demografik } \\
\text { Özellikler }\end{array}$ & & $f$ & $\%$ & $\begin{array}{l}\text { Demografik } \\
\text { Özellikler }\end{array}$ & & $f$ & $\%$ \\
\hline \multirow{2}{*}{ Cinsiyet } & Kadın & 20 & 62.5 & \multirow{6}{*}{$\begin{array}{l}\text { Annenin } \\
\text { Eğitim } \\
\text { Düzeyi }\end{array}$} & Okur-Yazar & 10 & 31.3 \\
\hline & Erkek & 12 & 37.5 & & İlkokul & 13 & 40.6 \\
\hline Kitap Okuma & İnternet & 9 & 28.1 & & Ortaokul & 4 & 12.5 \\
\hline Ortam1 & Basılı Kitap & 23 & 71.9 & & Lise & 5 & 15.6 \\
\hline \multirow{4}{*}{$\begin{array}{l}\text { Kitap } \\
\text { Sıklığ1 }\end{array}$} & Hiç & 4 & 12.5 & & Lisans & - & - \\
\hline & 0-30 Dakika & 18 & 56.3 & & Lisansüstü & - & - \\
\hline & 30-60 Dakika & 7 & 21.9 & \multirow{6}{*}{$\begin{array}{l}\text { Babanın } \\
\text { Eğitim } \\
\text { Düzeyi }\end{array}$} & Okur-Yazar & 1 & 3.1 \\
\hline & 60 Dakikadan Fazla & 3 & 9.4 & & İlkokul & 8 & 25.0 \\
\hline \multirow{4}{*}{ Kitap Türü } & Öykü-Roman & 21 & 65.6 & & Ortaokul & 7 & 21.9 \\
\hline & Gezi-Anı & 4 & 12.5 & & Lise & 12 & 37.5 \\
\hline & Bilimsel-Araştırma & 6 & 18.8 & & Lisans & 4 & 12.5 \\
\hline & Şiir & 1 & 3.1 & & Lisansüstü & - & - \\
\hline Toplam & & 32 & 100 & Toplam & & 32 & 100 \\
\hline
\end{tabular}

Tablo 1 incelendiğinde araştırmaya katılan öğrencilerin \%62.5'inin kadın, \%37.5'inin erkek; \%28.1'inin internet, \%71.9'unun basılı kitaptan okumayı sevdikleri; günlük kitap okuma süresine bakıldığında \%12.5'inin hiç, \%56.3'ünün 0-30 dakika, \%21.9'unun 30-60 dakika, \%9.4'ünün 60 dakikadan fazla kitap okudukları; okumayı tercih ettikleri kitap türüne göre \%65.6'sının öykü-roman, \%12.5'inin gezi-an1, \%18.8'inin bilimsel-araştırma, \%3.1'inin şiir türünde kitap okudukları; anne eğitim düzeyi bakımından \%31.3'ünün okur-yazar, \%40.6'sının ilkokul, \%12.5'inin ortaokul, \%15.6'sının lise; baba eğitim düzeyi bakımından \%3.1'inin okuryazar, \%25'inin ilkokul, \%21.9'unun ortaokul, \%37.5'inin lise, \%12.5'inin lisans mezunu oldukları görülmektedir.

Öğrenciler seçilirken Mersin ili merkez ilkokullarında yer alan sınıf öğretmenleri ve rehber öğretmenleriyle ön görüşmeler yapılmıştır. Görüşmeler sonunda Mersin il merkezindeki 18 ilkokulda dördüncü sınıfa giden ve okuma güçlüğü yaşayan toplamda 32 öğrenci çalışma grubu olarak belirlenmiştir. İlk aşama olarak öğrencilerin okuma düzeyini belirlemek için öğrencilere sırasıyla "Formel Olmayan Okuma Envanteri”"nde yer alan ikinci ve üçüncü düzey metinler okutulmuştur (Karasu, Girgin ve Uzuner, 2013). Öğrencilerin okumaları öğretmenleri tarafından kaydedilerek analiz edilmiştir. Analizler sonucunda öğrenciler için okutulması planlanan metinlerin üçüncü düzey metinlerden oluşması gerektiğine karar verilmiştir. Çalışma grubunda yer alan öğrencilerin seçimindeki temel ölçüt, "Endişe Düzeyi”nde okuma düzeyine sahip olmaları ve herhangi bir zihinsel, fiziksel, görsel ve işitsel engellerinin bulunmamasıdır. Öğrencilerin bu çalışmayı kabul etmeleri ve okuma becerilerinin gelişmesi yönünde istekli olmaları da dikkate alınmıştır. Çalışma kapsamında okul yönetimi, öğretmenler, aileler ve öğrencilere uygulama hakkında bilgiler verilmiş ve gerekli izinler kendilerinden alınmıștır.

\section{Veri Toplama Araçları}

Veri toplama aracı olarak öncelikle öğrencilerin demografik bilgilerini elde etmek için "Öğrenci Bilgi Formu" hazırlanmıştır. Hazırlanan formda öğrencilere ait cinsiyet, anne ve baba eğitim seviyesi, kitap okuma sıklıkları, tercih ettikleri kitap türü ve okuma ortamına ait bilgilere yer verilmiştir. İlkokul öğrencilerine okutulan metinler, ders kitaplarında bulunan ve öğrencilerin günlük yaşamlarında karşılaşabilecekleri olayları kapsayan konulardan seçilmiş metinlerden oluşmaktadır. Okutulan metinler öğrencilerin şu ana kadar hiç karşılaşmadıkları ve içerisinde yer alan metinleri okumadıkları bir kitap olan "Formel Olmayan Okuma Envanteri (FOOE)"de yer alan öykü ve bilgi verici metinlerden seçilmiştir. FOOE'de yer alan öykülerin 
bölümlerini değerlendirirken kurulum (yer, zaman, karakter), problem, içsel tepki, plan, girişim, girişimin sonucu ve sonuç bölümleri ele alınmıştır (Uzuner, Kırcaali-İftar ve Karasu, 2005). Güvenirlik açısından metinlerdeki öykü bölümlerinin tamlığına ilişkin güvenirlik hesaplanmış ve öğrencilerin okuması için seçilen "Ömer ve Güvercin” metninin düzeyi \%100 olarak bulunmuştur. Seçilen diğer metin, sosyal bilgiler alanından seçilen bilgi verici metinlerdendir. Bilgi verici metinlerde metnin organizasyonu, metnin bir bütün olarak algılanmasını, metindeki en önemli bilgilerin hatırlanması ve tanımlanmasını, diğer bir ifadeyle anlamayı etkilemektedir (Williams, 2005). Buna göre sosyal bilgiler alanında seçilen "Atatürk'ün Okul Hayatı" bilgi verici metin betimleme/açıklama ile derleme/bir araya getirme yapılarını içermektedir. Kitapta yer alan bilgi verici metnin yapısına ilişkin değerlendiriciler arası güvenirlik sözü edilen sınıf düzeylerinde \%100 hesaplanmıştır. FOOE'de yer alan metinlerin okunabilirlik düzeylerini belirlemek amaciyla metinlerde yer alan cümlelerin, diğer bir ifadeyle T-birimlerin ortalama uzunluğunu hesaplamak için her metindeki toplam sözcük sayısı toplam T-birim sayısına bölünmüştür. Yan cümlecik indeksi hesaplanırken de her bir metindeki toplam cümlecik sayısı toplam T-birim sayısına bölünür. Her T-birimin en az bir cümleciği olmak zorundadır dolayısıyla elde edilen puan her zaman için 1.0'dan büyük olacaktır. Elde edilen puanın 1.0'dan uzaklaşması öyküdeki cümlelerin zorluk derecelerini arttırırken, 1.0'a yaklaşması cümlelerin zorluk derecesini azaltır (Hughes, Mc Gillivray ve Schmidek, 1997; akt. Karasu, Girgin ve Uzuner, 2011). Seçilen öykü metni 2.03 yan cümlecik indeksine sahipken sosyal bilgiler alanından seçilen bilgi verici metnin yan cümlecik indeksinin 1.75 olduğu görülmüştür.

\section{Verilerin Analizi}

Okuma hatalarını değerlendirmede öğrencinin sesli okuduğu her cümle kodlanarak yapılan okuma hataları belirlenmektedir. Bunun ardından metinde yazan sözcükle öğrencinin okuduğu sözcük arasındaki harf-ses benzerliğinin değerlendirilmesi yapılmıştır. Öğrencilerin sesli okumaları sırasında yaptıkları başlıca okuma hataları; yerine koyma (yerine bir sözcük koyma, anlam değiştirmeyen hata yapma, birleşik hata, tersine çevirme, sözcük olmayanlar, diyalekt kullanımı, hatalı artikülasyon, tonlama değişikliği, heceleri bölme), ekleme yapma (metinde yazan dışında bir ya da daha fazla sözcük, ek, hece ilave etme), çıkarma yapma (sözcük/hece/ek çıkarma, cümlecik veya satır çıkarma, cümle sonundaki noktayı çıkarma), yanlış telaffuz (bir sözcüğü yanlış telaffuz etmeyle başlar fakat sözcüğü bitirmez ve o sözcügü okumak için girişimde bulunmaz), geri dönme (tekrar etme, doğru okuduğundan vazgeçme, doğru okuma girişimlerinde başarısız olma, hatayı düzeltme), duraklama yapma (okuma sırasında 5 saniyeden fazla duraklaması), yanlış okuma (metin boyunca aynı hatayı aynı sesleri kullanarak yapma, yerine bir sözcük koyma) şeklinde sınıflandırılmıştır (Allington ve McGill-Franzen, 1980; Davenport, 2002; Goodman, 1995; Leslie ve Caldwell, 2006). Öğrencilerin sesli okuma sırasında yaptıkları okuma hataları ve örnekleri Tablo 2'de gösterilmiştir. 
Tablo 2. Öğrencilerin Yaptıkları Okuma Hataları ve Örnekleri

\begin{tabular}{ll}
\hline Okuma Hataları & Örnek \\
\hline Yerine koyma & Yavru bir güvercin ağaçtaki yuvasından yere düşürdü (düşmüştü). \\
Ekleme yapma & Ömer yürüyerek onu (o) ağacın yanına gitti. \\
Çıkarma yapma & Bahçe (Bahçede) top oynuyordu. \\
Yanlış telaffuz & Soora (Sonra) merdivene çiktı ve yavru güvercini yuvaya bıraktı. \\
Geri dönme & Bunları düşünürken evde evde bir bir merdiven olduğunu olduğunu hatırladı. \\
Duraklama & Başını kaldı̈dı lllllll, gökyüzüne baktı. \\
Yanlış okuma & Bu (Bir) gün öğleden sonra Ömer yine bahçeye çıktı. \\
& Yavru bu (bir) güvercin ağaçtaki yuvasından yere düşmüştü. \\
\hline
\end{tabular}

Sesli okuma sırasında öğrencilerin hem öykü verici hem de sosyal bilgiler alanında hazırlanan bilgilendirici metin içerisinde yaptıkları hatalar ve hata sıklıkları çeşitli değişkenler açısından belirlenmeye çalışılmıştır. Çalışmada elde edilen veriler SPSS-21 programı aracılığıyla analiz edilmiştir. Veri girişinden sonra çalışma grubunun normal dağılım gösterip göstermediğini tespit etmek için çarpıklık değerleri ile grup büyüklüğü 50'den az olduğu için Shapiro-Wilks testine bakılmıştır. Cinsiyet, okuma ortamı, anne ve baba eğitim seviyesi, kitap okuma sıklığ1 ve tercih ettikleri kitap türüne göre çalışma grubunun normal dağılım gösterdiği tespit edilmiş, verilerin analizinde parametrik testlerden yararlanılmıştır. Öğrencilerin sesli okuma sırasında yaptıkları hatalar ve bu hataları hangi sıklıkta yaptıkları kelime tanıma düzeyine göre belirlendikten sonra; cinsiyet ve en çok tercih ettikleri okuma ortamına göre farklılaşıp farklılaşmadığının belirlenmesi için bağımsız gruplar t-testi kullanılmıştır. Öğrencilerin anne ve baba eğitim seviyesi, kitap okuma sıklıkları ve tercih ettikleri kitap türüne göre farklılaşmayı ortaya çıkarmak için tek yönlü varyans analizi (ANOVA) kullanılmıştır. Farklılaşmanın olduğu durumlarda, hangi gruplar arasında farklılaşmanın olduğunu tespit etmek amacıyla Tukey çoklu karşılaştırma testi kullanılmıştır. (Büyüköztürk, 2007).

\section{BULGULAR VE YORUM}

Bu bölümde okuma güçlüğü yaşayan ilkokul öğrencilerinin sesli okuma sırasında hem öykü verici hem de bilgilendirici metin içerisinde yaptıkları hatalar ve hata sıklıklarının demografik değişkenlere göre dağılımına ilişskin bulgular yer almaktadır. Okuma güçlüğü yaşayan öğrencilerin öykü ve bilgi verici metinlerde yaptıkları okuma hatalarının demografik değişkenlere (cinsiyetleri, en çok tercih ettikleri okuma ortamı, anne ve baba eğitim seviyesi, kitap okuma sıklıkları ve tercih ettikleri kitap türü) göre farklılık gösterip göstermediğine ilişkin bulgular aşağıda verilmiştir.

Okuma güçlüğ̈̈ yaşayan öğrencilerin yaptıkları okuma hatalarının cinsiyet ve en çok tercih ettikleri okuma ortamı değişkenleri açısından farklılaşmayı ortaya çıkarmak için bağımsız gruplar t-testi kullanılmıştır. Okuma hatalarının cinsiyete göre dağılımı Tablo 3 'te verilmiştir. 
Tablo 3. Okuma Hatalarının Cinsiyete Göre Dağılımı

\begin{tabular}{|c|c|c|c|c|c|}
\hline \multirow[t]{2}{*}{ Metinler } & \multirow[t]{2}{*}{ Okuma Hataları } & \multicolumn{2}{|c|}{$\begin{array}{l}\text { Cinsiyete Göre Hata Yapan } \\
\text { Öğrenci Sayısı }\end{array}$} & \multirow[t]{2}{*}{$\mathrm{T}$} & \multirow[t]{2}{*}{$\mathrm{P}$} \\
\hline & & $\operatorname{Kad} \ln (\mathrm{N}=20)$ & Erkek $(\mathrm{N}=12)$ & & \\
\hline \multirow{7}{*}{ Öykü } & Yerine koyma & 11 & 6 & -.266 & .792 \\
\hline & Ekleme yapma & 7 & 9 & 2.301 & .029 \\
\hline & Çıkarma yapma & 10 & 6 & .000 & 1.00 \\
\hline & Yanlış telaffuz & 15 & 3 & -3.062 & .005 \\
\hline & Geri dönme & 9 & 5 & -.178 & .860 \\
\hline & Duraklama & 7 & 7 & 1.281 & .210 \\
\hline & Yanlış okuma & 7 & 4 & -.093 & .926 \\
\hline \multirow{7}{*}{ Bilgi Verici Metin } & Yerine koyma & 13 & 8 & .093 & .926 \\
\hline & Ekleme yapma & 10 & 9 & 1.393 & .174 \\
\hline & Çıkarma yapma & 11 & 9 & 1.118 & .272 \\
\hline & Yanlıș telaffuz & 14 & 5 & -1.593 & .122 \\
\hline & Geri dönme & 6 & 5 & .656 & .517 \\
\hline & Duraklama & 6 & 6 & 1.118 & .272 \\
\hline & Yanlıș okuma & 10 & 5 & -.444 & .660 \\
\hline
\end{tabular}

Tablo 3'e göre okuma güçlüğü yaşayan ilkokul öğrencilerinin öykü metninde yaptıkları okuma hatalarından ekleme yapma ve yanlış telaffuz arasında cinsiyet değişkenine göre anlamlı bir fark olduğu görülmüştür $[\mathrm{t}(30)=2.30, \mathrm{p}<.05 ; \mathrm{t}(30)=-3.06, \mathrm{p}<.05]$. Hem öykü hem de bilgi verici metinlerde yapılan diğer okuma hataları arasında cinsiyet değişkenine göre anlamlı bir farklılık olmadığı görülmüştür. Hata yapan öğrenci sayısına bakıldığında her iki metinde de kadın öğrencilerin erkek öğrencilere göre daha yüksek oranda hata yaptıkları görülmektedir. Sadece öykü metninde erkek öğrenciler kadın öğrencilere göre ekleme yapma hatasını daha çok yapmışlardır. Bu bulgu, okuma hataları ile cinsiyet arasında yerine koyma, çıkarma yapma, geri dönme, duraklama, yanlış okuma hataları arasında anlamlı bir ilişkinin olmadığı şeklinde yorumlanabilir. Okuma hatalarının okuma ortamına göre dağılımı Tablo 4 'te verilmiştir.

Tablo 4. Okuma Hatalarının Okuma Ortamına Göre Dağılımı

\begin{tabular}{|c|c|c|c|c|c|}
\hline \multirow[t]{2}{*}{ Metinler } & \multirow[t]{2}{*}{ Okuma Hataları } & \multicolumn{2}{|c|}{$\begin{array}{l}\text { Okuma Ortamına Göre Hata Yapan } \\
\text { Öğrenci Sayısı }\end{array}$} & \multirow[t]{2}{*}{$\mathrm{T}$} & \multirow[t]{2}{*}{$\mathrm{P}$} \\
\hline & & Internet $(\mathrm{N}=9)$ & Basılı Kitap $(\mathrm{N}=23)$ & & \\
\hline \multirow{7}{*}{ Öykü } & Yerine koyma & 4 & 13 & .600 & .553 \\
\hline & Ekleme yapma & 4 & 12 & .382 & .705 \\
\hline & Çıkarma yapma & 2 & 14 & 2.030 & .051 \\
\hline & Yanlış telaffuz & 7 & 11 & -1.545 & .133 \\
\hline & Geri dönme & 3 & 11 & .726 & .474 \\
\hline & Duraklama & - & 14 & 3.623 & .001 \\
\hline & Yanlış okuma & 4 & 7 & -.733 & .469 \\
\hline \multirow{7}{*}{$\begin{array}{l}\text { Bilgi } \\
\text { Verici } \\
\text { Metin }\end{array}$} & Yerine koyma & 6 & 15 & -.075 & .941 \\
\hline & Ekleme yapma & 5 & 14 & .267 & .791 \\
\hline & Çıkarma yapma & 5 & 15 & .493 & .625 \\
\hline & Yanlış telaffuz & 7 & 12 & -1.321 & .197 \\
\hline & Geri dönme & 4 & 7 & -.733 & .469 \\
\hline & Duraklama & 1 & 11 & 1.987 & .056 \\
\hline & Yanlış okuma & 4 & 11 & .167 & .869 \\
\hline
\end{tabular}

Tablo 4'e göre okuma güçlüğü yaşayan ilkokul öğrencilerinin öykü metninde yaptıkları okuma hatalarından duraklama hatasında okuma ortamı değişkenine göre anlamlı bir fark olduğu görülmüştür $[t(30)=3.62, p<.05]$. Hem öykü hem de bilgi verici metinlerde yapılan diğer okuma hataları arasında okuma ortamı değişkenine göre anlamlı bir farklılık olmadığı görülmektedir. 
Hata yapan öğrenci sayısına bakıldığında her iki metinde de basılı kitap okuyan öğrencilerin internet ortamında okuyan öğrencilere göre daha fazla hata yaptıkları görülmektedir. Bu bulgu, okuma hataları ile okuma ortamı arasında yerine koyma, ekleme yapma, çıkarma yapma, yanlış telaffuz, geri dönme ve yanlış okuma hataları arasında anlamlı bir ilişkinin olmadığı şeklinde yorumlanabilir.

Okuma güçlüğü yaşayan öğrencilerin yaptıkları okuma hatalarının anne ve baba eğitim seviyesi, kitap okuma sıklıkları ve tercih ettikleri kitap türü değişkenleri açısından farklılaşmayı ortaya çıkarmak için tek yönlü varyans analizi (ANOVA) kullanılmıştır. Okuma hatalarının annelerinin eğitim seviyesine göre dağılımı Tablo 5’te verilmiştir.

Tablo 5. Okuma Hatalarının Annelerinin Eğitim Seviyesine Göre Dağılımı

\begin{tabular}{|c|c|c|c|c|c|c|c|}
\hline \multirow[t]{2}{*}{ Metinler } & \multirow[t]{2}{*}{ Okuma Hataları } & \multicolumn{4}{|c|}{$\begin{array}{l}\text { Annelerinin Eğitim Seviyesine Göre Hata Yapan } \\
\text { Öğrenci Sayısı }\end{array}$} & \multirow[b]{2}{*}{$\mathrm{F}$} & \multirow[b]{2}{*}{$\mathrm{p}$} \\
\hline & & $\begin{array}{l}\text { Okur-Yazar } \\
(\mathrm{N}=10)\end{array}$ & $\begin{array}{l}\text { İlkokul } \\
(\mathrm{N}=13)\end{array}$ & $\begin{array}{l}\text { Ortaokul } \\
(\mathrm{N}=4)\end{array}$ & $\begin{array}{l}\text { Lise } \\
(\mathrm{N}=5)\end{array}$ & & \\
\hline \multirow{7}{*}{ Öykü } & Yerine koyma & 4 & 8 & 2 & 3 & .355 & .786 \\
\hline & Ekleme yapma & 8 & 4 & 1 & 3 & 2.482 & .081 \\
\hline & Çıkarma yapma & 3 & 9 & 2 & 2 & 1.229 & .318 \\
\hline & Yanlış telaffuz & 4 & 7 & 2 & 5 & 1.751 & .179 \\
\hline & Geri dönme & 4 & 7 & 1 & 2 & .362 & .781 \\
\hline & Duraklama & 5 & 6 & 2 & 1 & .427 & .735 \\
\hline & Yanlış okuma & 5 & 4 & 1 & 1 & .547 & .654 \\
\hline \multirow{7}{*}{$\begin{array}{l}\text { Bilgi } \\
\text { Verici } \\
\text { Metin }\end{array}$} & Yerine koyma & 6 & 9 & 3 & 3 & .130 & .941 \\
\hline & Ekleme yapma & 10 & 6 & 1 & 2 & 4.572 & .010 \\
\hline & Çıkarma yapma & 6 & 9 & 2 & 3 & .166 & .919 \\
\hline & Yanlış telaffuz & 7 & 5 & 2 & 5 & 2.330 & .096 \\
\hline & Geri dönme & 3 & 5 & 1 & 2 & .120 & .947 \\
\hline & Duraklama & 4 & 5 & 2 & 1 & .286 & .835 \\
\hline & Yanlış okuma & 4 & 7 & 1 & 2 & .350 & .789 \\
\hline
\end{tabular}

Tablo 5'e göre okuma güçlüğü yaşayan ilkokul öğrencilerinin bilgi verici metinlerde yaptıkları okuma hatalarından sadece ekleme hatasında annelerinin eğitim seviyesi değişkenine göre farklılık olduğu görülmüştür $[\mathrm{F}(3-28)=4.57, \mathrm{p}<.05]$. Öğrencilerin okudukları metinlerde yaptıkları diğer hatalarda annelerinin eğitim seviyesine göre anlamlı bir farklılık olmadığı görülmüştür. Gruplararası farkların belirlenmesi amacıyla yapılan Tukey testinin sonuçlarına göre de yapılan hataların anne eğitim seviye durumuna göre farklılaşmadığ 1 bulgusuna ulaşılmıştır. Annesi okur-yazar seviyeye sahip okuma güçlüğü yaşayan öğrencilerin en çok hatayı ekleme yapma; ilkokul mezunu olanların çıkarma yapma ve yerine koyma; ortaokul mezunu olanların yerine koyma ve lise mezunu olanların da yanlış telaffuz hatasını yaptıkları görülmektedir. Okuma hatalarının babalarının eğitim seviyesine göre dağılımı Tablo 6'da verilmiştir. 
Tablo 6. Okuma Hatalarının Babalarının Eğitim Seviyesine Göre Dağılımı

\begin{tabular}{|c|c|c|c|c|c|c|c|c|}
\hline \multirow[t]{2}{*}{ Metinler } & \multirow[t]{2}{*}{ Okuma Hataları } & \multicolumn{5}{|c|}{$\begin{array}{l}\text { Babalarının Eğitim Seviyesine Göre Hata Yapan Öğrenci } \\
\text { Sayısı }\end{array}$} & \multirow[b]{2}{*}{$\mathrm{F}$} & \multirow[b]{2}{*}{$\mathrm{p}$} \\
\hline & & $\begin{array}{l}\text { Okur-Yazar } \\
(\mathrm{N}=1)\end{array}$ & $\begin{array}{l}\text { İlkokul } \\
(\mathrm{N}=8)\end{array}$ & $\begin{array}{l}\text { Ortaokul } \\
(\mathrm{N}=7)\end{array}$ & $\begin{array}{l}\text { Lise } \\
(\mathrm{N}=12)\end{array}$ & $\begin{array}{l}\text { Lisans } \\
(\mathrm{N}=4)\end{array}$ & & \\
\hline \multirow{7}{*}{ Öykü } & Yerine koyma & - & 5 & 2 & 7 & 3 & .967 & .442 \\
\hline & Ekleme yapma & - & 6 & 2 & 6 & 2 & 1.044 & .403 \\
\hline & Çıkarma yapma & 1 & 3 & 4 & 6 & 2 & .365 & .831 \\
\hline & Yanlış telaffuz & 1 & 4 & 4 & 7 & 2 & .216 & .927 \\
\hline & Geri dönme & - & 4 & 4 & 5 & 1 & .452 & .770 \\
\hline & Duraklama & 1 & 3 & 4 & 5 & 1 & 1.160 & .350 \\
\hline & Yanlış okuma & 1 & 4 & 1 & 5 & - & 1.689 & .182 \\
\hline \multirow{7}{*}{$\begin{array}{l}\text { Bilgi } \\
\text { Verici } \\
\text { Metin }\end{array}$} & Yerine koyma & 1 & 5 & 5 & 7 & 4 & .740 & .573 \\
\hline & Ekleme yapma & 1 & 7 & 2 & 7 & 2 & 1.626 & .196 \\
\hline & Çıkarma yapma & 1 & 5 & 2 & 9 & 3 & 1.281 & .302 \\
\hline & Yanlış telaffuz & 1 & 6 & 2 & 8 & 2 & 1.150 & .355 \\
\hline & Geri dönme & - & 2 & 3 & 5 & 1 & .331 & .854 \\
\hline & Duraklama & 1 & 3 & 4 & 2 & 2 & 1.342 & .280 \\
\hline & Yanlıș okuma & 1 & 4 & 3 & 7 & - & 1.362 & .273 \\
\hline
\end{tabular}

Tablo 6'ya göre okuma güçlüğü yaşayan ilkokul öğrencilerinin hem öykü hem de bilgi verici metinlerde yaptıkları okuma hatalarının babalarının eğitim seviyesi değişkenine göre farklılık göstermediği görülmüştür. Gruplararası farkların belirlenmesi amacıyla yapılan Tukey testinin sonuçlarına göre yapılan hataların baba eğitim seviye durumuna göre farklılaşmadığı bulgusuna ulaşılmış̧ır. Babası ilkokul mezunu olan ve okuma güçlüğü yaşayan öğrencilerin en çok hatayı ekleme yapmada, ortaokul mezunu olanların yerine koymada, lise mezunu olanların çıkarma yapma ve lisans mezunu olanların da yerine koyma hatasını yaptıkları görülmektedir. Okuma hatalarının kitap okuma sıklığına göre dağılımı Tablo 7'de verilmiştir.

Tablo 7. Okuma Hatalarının Kitap Okuma Sıklığına Göre Dağılımı

\begin{tabular}{llllllll}
\hline Metinler & Okuma Hataları & \multicolumn{6}{l}{ Kitap Okuma Siklığına Göre Hata Yapan Öğrenci Sayıs1 } \\
\cline { 3 - 8 } & & $\begin{array}{l}\text { Hiç } \\
(\mathrm{N}=4)\end{array}$ & $\begin{array}{l}0-30 \text { Dakika } \\
(\mathrm{N}=18)\end{array}$ & $\begin{array}{l}30-60 \text { Dakika } \\
(\mathrm{N}=7)\end{array}$ & $\begin{array}{l}\text { 60 Dakikadan } \\
\text { Fazla (N=3) }\end{array}$ & F & $\mathrm{p}$ \\
\hline \multirow{6}{*}{ Öykü } & Yerine koyma & 1 & 11 & 4 & 1 & .705 & .557 \\
& Ekleme yapma & 3 & 8 & 4 & 1 & .523 & .670 \\
& Çıarma yapma & 1 & 9 & 6 & 1 & .832 & .488 \\
& Yanlış telaffuz & 4 & 6 & 5 & 2 & 4.206 & .014 \\
& Geri dönme & 2 & 10 & 2 & - & 1.361 & .275 \\
& Duraklama & 1 & 10 & 3 & - & 1.305 & .292 \\
& Yanlış okuma & 2 & 6 & 3 & - & .701 & .559 \\
\hline \multirow{5}{*}{ Bilgi } & Yerine koyma & 2 & 13 & 4 & 4 & .303 & .823 \\
Verici & Ekleme yapma & 5 & 10 & 4 & 1 & 1.222 & .320 \\
Metin & Çıarma yapma & 2 & 11 & 6 & 2 & .161 & .922 \\
& Yanlış telaffuz & 4 & 8 & 4 & 3 & 2.364 & .092 \\
& Geri dönme & 1 & 7 & 2 & 1 & .125 & .944 \\
& Duraklama & 1 & 9 & 2 & - & 1.148 & .347 \\
& Yanlış okuma & 2 & 8 & 5 & - & 1.488 & .239 \\
\hline
\end{tabular}


Tablo 7'ye göre okuma güçlüğü yaşayan ilkokul öğrencilerinin öykü metnini okurken yaptıkları okuma hatalarından yanlış telaffuz hatasında kitap okuma sıklığı değişkenine göre farklılık olduğu görülmüştür $[\mathrm{F}(3-28)=4.206, \mathrm{p}<.05]$. Öğrencilerin okudukları metinlerde yaptıkları diğer hatalarda kitap okuma sıklığı değişkenine göre anlamlı bir farklılık olmadığı görülmüştür. Gruplar arası farkların belirlenmesi amacıyla yapılan Tukey testinin sonuçlarına göre de yapılan hataların kitap okuma sıklığına göre farklılaşmadığı bulgusuna ulaşılmıştır. Günde hiç kitap okumayan öğrencilerin en çok hatayı ekleme yapmada; 0-30 dakika okuyanların yerine koyma ve çıkarma yapmada; 30-60 dakika okuyanların çıkarma yapmada ve 60 dakikadan fazla okuyanların da yerine koymada yaptıkları görülmektedir. Okuma hatalarının tercih ettikleri kitap türüne göre dağılımı Tablo 8'de verilmişstir.

Tablo 8. Okuma Hatalarının Tercih Ettikleri Kitap Türüne Göre Dağılımı

\begin{tabular}{|c|c|c|c|c|c|c|c|}
\hline \multirow[t]{2}{*}{ Metinler } & \multirow[t]{2}{*}{ Okuma Hataları } & \multicolumn{4}{|c|}{ Tercih Ettikleri Kitap Türüne Göre Hata Yapan Öğrenci Sayıs1 } & \multirow[b]{2}{*}{$\mathrm{F}$} & \multirow[b]{2}{*}{$\mathrm{p}$} \\
\hline & & $\begin{array}{l}\text { Öykü-Roman } \\
(\mathrm{N}=21)\end{array}$ & $\begin{array}{l}\text { Gezi-Anı } \\
(\mathrm{N}=4)\end{array}$ & $\begin{array}{l}\text { Bilimsel- } \\
\text { Araştırma }(\mathrm{N}=6)\end{array}$ & $\begin{array}{l}\text { Şiir } \\
(\mathrm{N}=1)\end{array}$ & & \\
\hline \multirow{7}{*}{ Öykü } & Yerine koyma & 12 & 1 & 4 & - & .959 & .426 \\
\hline & Ekleme yapma & 11 & 2 & 3 & - & .316 & .814 \\
\hline & Çıkarma yapma & 12 & 1 & 2 & 1 & .999 & .408 \\
\hline & Yanlış telaffuz & 10 & 5 & 3 & 1 & 1.575 & .218 \\
\hline & Geri dönme & 9 & 2 & 2 & 1 & .498 & .687 \\
\hline & Duraklama & 11 & 1 & 2 & - & .706 & .557 \\
\hline & Yanlış okuma & 10 & - & 1 & - & 1.764 & .177 \\
\hline \multirow{7}{*}{$\begin{array}{l}\text { Bilgi } \\
\text { Verici } \\
\text { Metin }\end{array}$} & Yerine koyma & 14 & 1 & 5 & 1 & 1.447 & .250 \\
\hline & Ekleme yapma & 14 & 1 & 3 & 2 & 1.082 & .373 \\
\hline & Çıkarma yapma & 12 & 2 & 5 & 1 & .701 & .560 \\
\hline & Yanlış telaffuz & 10 & 4 & 4 & 1 & 1.630 & .205 \\
\hline & Geri dönme & 7 & 2 & 1 & 1 & 1.032 & .394 \\
\hline & Duraklama & 9 & 1 & 2 & - & .354 & .787 \\
\hline & Yanlış okuma & 13 & 1 & 1 & - & 2.046 & .130 \\
\hline
\end{tabular}

Tablo 8'e göre okuma güçlüğü yaşayan ilkokul öğrencilerinin hem öykü hem de bilgi verici metinlerde yaptıkları okuma hatalarının tercih ettikleri kitap türü değişkenine göre farklılık göstermediği görülmüştür. Gruplararası farkların belirlenmesi amacıyla yapılan Tukey testinin sonuçlarına göre yapılan hataların tercih ettikleri kitap türüne göre farklılaşmadığı bulgusuna ulaşılmıştır. Öykü-roman türünde kitap okumayı tercih eden öğrencilerin en çok hatayı yerine koyma ve ekleme yapmada, gezi-anı türünde kitap okumayı tercih eden öğrencilerin yanlış telaffuz, bilimsel-araştırma türünde kitap okumayı tercih eden öğrencilerin yerine koyma, şiir türünde kitap okumayı tercih eden öğrencilerin de ekleme yapma hatasını yaptıkları görülmektedir.

\section{SONUÇLAR VE ÖNERÍLER}

Bu çalışma, okuma güçlüğü yaşayan ilkokul dördüncü sınıf öğrencilerinin sesli okuma sırasında yaptıkları okuma hatalarının çeşitli değişkenler açısından farklılık gösterip göstermediğini belirlemek amacıyla yapılmıştır. Okuma güçlügüü yaşayan ilkokul öğrencilerinin öykü metninde yaptıkları okuma hatalarından ekleme yapma ve yanlış telaffuz arasında cinsiyet değişkenine göre anlamlı bir farka yol açtığı görülürken hem öykü hem de bilgi verici metinlerde yapılan diğer okuma hataları arasında ise farklılığa yol açmadığı görülmüştür. Araştırmadan elde edilen 
sonuçlara göre her iki metinde de kadın öğrencilerin erkek öğrencilere göre daha yüksek oranda hata yaptıkları görülmektedir. Bu bulgu, Bilge ve Sağır (2017)'nin ortaokul öğrencilerinin okuma hatalarını inceledikleri çalışmalarıyla farklı sonuçlar elde edildiğini göstermektedir. Araştırmacılar çalışmalarında çocukların yaptıkları sesli okuma hatalarını cinsiyet, sınıf düzeyi, karnedeki Türkçe dersi notu, günlük kitap okuma süresi ve yıllık okunan kitap sayısına göre karşılaştırmışlardır. Ancak sadece cinsiyete göre atlama hatası arasında anlamlı fark bulmuşlardır. Buna göre kızlar erkeklerden anlamlı ölçüde daha az hata yapmıştır.

Çalışmada okuma güçlüğü yaşayan ilkokul öğrencilerinin okuma ortamı değişkenine göre öykü metninde yaptıkları okuma hatalarından duraklama hatasında anlamlı bir fark olduğu, diğer okuma hataları arasında ise anlamlı bir farklılık olmadığı görülmektedir. Hata yapan öğrenci sayısına bakıldığında her iki metinde de basılı kitabı okuyan öğrencilerin internet ortamında okuyan öğrencilere göre daha fazla hata yaptıkları görülmektedir. Bu bulgu "yeni bin yıl ögrencileri" ya da "Z kuşă̆l" denilen yeni nesil çocukların bilgisayar, tablet ve akıllı telefonlarla çevrili bir ortamda yaşamalarına bağlanabilir (Ohler, 2013; Pedró, 2006; Savaş \& Karataş, 2019). Çünkü bu nesil internetin olmadığı bir dönemi hiç yaşamamıştır. Dolayısıyla günümüz çocukları internet ortamında daha rahat okudukları için basılı kitap daha çok hata yapabilecekleri bir okuma ortamı haline gelmiş olabilir.

Okuma güçlüğü yaşayan ilkokul öğrencilerinin annelerinin eğitim düzeyine göre bilgi verici metinlerde yaptıkları okuma hatalarından sadece ekleme hatasında anlamlı bir fark olduğu görülmüştür. Öğrencilerin okudukları metinlerde yaptıkları diğer hatalarda annelerinin eğitim seviyesine göre anlamlı bir farklılık olmadığı görülmüştür. Annesi okur-yazar seviyeye sahip okuma güçlügü yaşayan öğrencilerin en çok ekleme yapma; ilkokul mezunu olanların çıkarma yapma ve yerine koyma; ortaokul mezunu olanların yerine koyma ve lise mezunu olanların da yanlış telaffuz hatasını yaptıkları görülmektedir. Dolayısıyla anne eğitim düzeyiyle yapılan okuma hatalarının birbiriyle ilişkili olmadığı görülmüştür. Annelerinin eğitim düzeyine göre öğrencilerin sayıları birbirine denk hale getirildiği zaman annesi ilkokul mezunu olan öğrencinin yaptığı okuma hatasının sayısıyla, annesi lise mezunu olan öğrencinin arasında fark olmadığı sonucuna ulaşılabilir. Aynı şekilde okuma güçlüğü yaşayan ilkokul öğrencilerinin hem öykü hem de bilgi verici metinlerde yaptıkları okuma hatalarının babalarının eğitim seviyesi değişkenine göre farklılık göstermediği sonucuna ulaşılmıştır. Babası ilkokul mezunu olan ve okuma güçlüğü yaşayan öğrencilerin en çok ekleme yapma, ortaokul mezunu olanların yerine koyma, lise mezunu olanların çıkarma yapma ve lisans mezunu olanların da yerine koyma hatasını yaptıkları görülmektedir. Burada da baba eğitim düzeyiyle yapılan okuma hatalarının birbiriyle ilişkili olmadığı sonucu çıkmaktadır.

Araştırma bulgularında okuma güçlüğü yaşayan ilkokul öğrencilerinin öykü metnini okurken yaptıkları okuma hatalarından yanlış telaffuz hatasında kitap okuma sıklığı değişkenine göre anlamlı bir farklılık olduğu sonucuna ulaşılmıştır. Öğrencilerin okudukları metinlerde yaptıkları diğer hatalarda okuma sıklığı değişkenine göre anlamlı bir farklılık olmadığı görülmüştür. Günde hiç kitap okumayan öğrencilerin en çok hatayı ekleme yapmada; 0-30 dakika okuyanların yerine koyma ve çıkarma yapma; 30-60 dakika okuyanların çıkarma yapma ve 60 dakikadan fazla okuyanların da yerine koyma hatasını yaptıkları görülmektedir. Sonuçta en çok hatayı ekleme ve çıkarma yapmada yaptıkları görülmüştür. Demir (2015) yüksek lisans çalışmasında ilkokul öğrencilerinin okuma hızları ve heceleyerek okuyup okumadıklarını incelediğinde öğrencilerin okuma düzeyleri ile okuma hızları arasında anlamlı bir ilişki olduğu sonucuna ulaşmıştır. Bu bulgu günlük kitap okuma süresiyle okuma hızının da ilişkili olduğu sonucunu çıkarmaktadır. 
Okuma güçlüğü yaşayan ilkokul öğrencilerinin hem öykü hem de bilgi verici metinlerde yaptıkları okuma hatalarının tercih ettikleri kitap türü değişkenine göre farklılaşmadığı bulgusuna ulaşılmıştır. Öykü-roman türünde kitap okumayı tercih eden öğrencilerin en çok hatayı yerine koyma ve ekleme yapmada, gezi-anı türünde kitap okumayı tercih eden öğrencilerin yanlış telaffuz, bilimsel-araştırma türünde kitap okumayı tercih eden öğrencilerin yerine koyma, şiir türünde kitap okumayı tercih eden öğrencilerin de ekleme yapma hatasını yaptıkları sonucuna ulaşılmıştır. Benzer şekilde Demir (2015) araştırmasında hata sayısı ile metnin konusu arasında bir ilişki olduğunu bulmuştur. Araştırmada aynı zamanda öğrencilerin, ilgilerini çeken ve gerçek yaşamla ilişkili olan öyküleyici metinlerde daha az hata yaparken ilgilerini çekmeyen çok fazla öğretim amacı güden bilgilendirici metinlerde daha fazla hata yaptıkları tespit edilmiştir.

Sonuçta demografik özelliklerin okuma güçlüğü yaşayan ilkokul öğrencilerinin yaptıkları okuma hataları üzerinde farklılık yaratmadığı sonucuna ulaşılmıştır. Dolayısıyla sesli okuma hatalarında demografik özelliklerin belirgin bir hatanın öne çıkmasında etkili olmadığı, hataların sıklıklarının farklı özelliklerde olduğu söylenebilir (Akyol \& Kodan, 2016; Ateş \& Yıldız, 2011; Baydık, Ergül \& Bahap-Kudret, 2012; Sidekli, 2010; Y1lmaz, 2006). Yılmaz (2008), okuma güçlüğü yaşayan ilköğretim sekizinci sınıf öğrencilerinin üç tür sesli okuma hatası yaptığını tespit etmiştir. Bunlar; atlama, ekleme ve yanlış okuma hatalarıdır. Aynı şekilde Demir (2015) sesli okuma sırasında yapılan hata türlerini incelediğinde öğrencilerin en sık yanlış okuma (215), atlayıp geçme (158) ve ekleme yapma (82) hatasını yaptıklarını tespit etmiştir. Kuruoğlu ve Şen (2018), öğrencilerin okuma sırasında yaptıkları hataları tiplerine göre incelediğinde üç tip okuma hatası görmüştür: düşürme, ekleme ve değiştirme. Bu hata tipleri incelendiğinde, okuma sırasında öğrenciler en fazla değiştirme, en az ekleme hatasını yaptıkları görülmüştür. Yapılan çalışmalarda okuma güçlüğü olan öğrencilerin en sık yaptıkları hataların yanlış okuma, harf/hece karıştırma, atlama ve ekleme yapma olduğu görülmüştür (GökçeSarıpınar \& Erden, 2010; Seçkin, 2012).

Çalışmadan elde edilen sonuçlara göre ilkokul seviyesindeki öğrencilerin okumaya yönelik hatalarını azaltmaya ve akıcı okuma becerilerini arttırmaya yönelik çalışmaların daha çok yapılması gerektiği düşünülmektedir. Akıcı okuma becerilerini geliştirmede uygulamaya yönelik kullanılacak yöntem ve teknikler hakkında öğretmenlere bilgi verilmelidir. Ebeveynlerin de hem öğrencilere bu konuda yardımcı olmaları hem de öğretmenin sorumluluğunu paylaşmaları için bilgilendirilmeleri gerekir. İlkokul akıcı okuma anlamında temel kademe olmasına karşın ortaokul ve lise kademesinde de bu sorunların olduğu görülmekte ve çalışmaların bu kademelerde de yapılması gerektiği görülmektedir. Bu sebeple tarama çalışmaları yapılıp endişe düzeyindeki öğrencilerin tespiti ve önleme çalışmalarının yapılması önerilmektedir. Önleme çalışmalarının yapılması ile öğrencilerin okuma güçlügünün giderilmesi gerektiğgi düşünülmektedir.

\section{KAYNAKÇA}

Akyol, H. (2012). Türkçe ilk okuma yazma öğretimi. Pegem Akademi Yayınları.

Akyol, H. (2013). Programa uygun Türkçe öğretim yöntemleri. Pegem Akademi Yayınları.

Akyol, H., \& Kodan, H. (2016). Okuma güçlüğünün giderilmesine yönelik bir uygulama: Akıcı okuma stratejilerinin kullanımı. Ondokuz Mayıs Üniversitesi Ĕ̈itim Fakültesi Dergisi, 35(2), 7-21.

Akyol, H., \& Ketenoğlu Kayabaşı, Z. (2018). Okuma güçlüğü yaşayan bir öğrencinin okuma becerilerinin geliştirilmesi: Bir eylem araştırması. Eğitim ve Bilim, 43(193), 143-158. 
Akyol, H. \& Sever, E. (2019). Okuma yazma güçlüğü ve bir eylem araştırmasi: İkinci sınıf örneği. Hacettepe Üniversitesi Eğitim Fakültesi Dergisi, 34(3), 685-707.

Allington, R. L., \& McGill-Franzen, A. (1980). Word identification errors in isolation and in context: Apples vs. oranges. The Reading Teacher, 33, 795-800.

Ateş, S., \& Yıldız, M. (2011). Okumayı farklı yöntemlerle öğrenen ilköğretim üçüncü sınıf öğrencilerinin sesli okuma akıcılıklarının karşılaştırılması. Türk Eğitim Bilimleri Dergisi, 9(1), 101-124.

Baydık, B., Ergül, C., \& Bahap Kudret, Z. (2012). Okuma güçlüğü olan öğrencilerin okuma akıcılığı sorunları ve öğretmenlerinin bu sorunlara yönelik öğretim uygulamaları. İlköğretim Online, 11(3), 778-789.

Bilge, H., \& Sağır, M. (2017). Ortaokul öğrencilerinin okuma hatalarının çeşitli değişkenlere göre incelenmesi. Ihlara Eğitim Araştırmaları Dergisi, 2(1), 77-88.

Büyüköztürk, Ş. (2007). Sosyal bilimler için veri analizi el kitabı. Pegem Akademi Yayıncılık.

Büyüköztürk, Ş., Kılıç-Çakmak, E., Akgün, Ö. E., Karadeniz, Ş., \& Demirel, F. (2016). Bilimsel araştırma yöntemleri (20. Baskı). Pegem Akademi Yayıncilık.

Creswell, J. W., \& Creswell, J. D. (2018). Research design: qualitative, quantitative, and mixed methods approaches (5th $E d$.). SAGE.

Daly, E. J., Chafouleas, S., \& Skinner, C. H. (2005). Interventions for reading problems. Te Guilford Press.

Dağ, N. (2010). Okuma güçlüğünün giderilmesinde 3P metodu ile boşluk tamamlama (Cloze) tekniğinin kullanımı üzerine bir çalışma. Ankara Üniversitesi Eğitim Bilimleri Fakültesi Özel Eğitim Dergisi, 11(1) 63-74.

Davenport, M. R. (2002). Miscues not mistakes: Reading assessment in the classroom. Heinemann.

Demir, H. (2015). Yanlış Analizi Envanteri'nin ilkokul öğrencilerinin okumalarının değerlendirilmesinde kullanımı. [Yayımlanmamış yüksek lisans tezi]. Hacettepe Üniversitesi.

Doğangün, B. (2008). Özel eğitim gerektiren psikiyatrik durumlar. Türkiye'de Stk Karşılaşılan Psikiyatrik Hastalıklar Sempozyum Dizisi No:62, İstanbul Üniversitesi, 157-174.

Goodman, Y. M. (1995). Miscue analysis for classroom teachers: Some history and some procedures. Primary Voices $K-6,3(4), 2-9$.

Gökçe-Sarıpınar, E., \& Erden, G. (2010). Okuma güçlüğünde akademik beceri ve duyusal-motor işlevleri değerlendirme testlerinin kullanılabilirliği. Türk Psikoloji Dergisi, 25(65), 56-66.

Hughes, D., Mc Gillivray, L., \& Schmidek, M. (1997). Guide to narrative language: Procedures for assessment. Thinking Publication.

Karasu, H. P., Girgin, Ü., \& Uzuner, Y. (2011). Okuma becerilerini değerlendirmede formel olmayan okuma envanterlerinin kullanımı. Eğitim Teknolojisi Kuram ve Uygulama, 1(1), 108-124.

Karasu, H. P., Girgin, Ü., \& Uzuner, Y. (2013). Formel olmayan okuma envanteri. Nobel Kitabevi.

Karatay, H. (2013). Türkçe öğretimi el kitabı. A. Güzel, H. Karatay (Editörler), Okuma Eğitimi: kuram, uygulama, ölçme ve değerlendirme içinde (ss. 221-264). Pegem Akademi Yayınları.

Keser Özmantar, Z. (2019). Eğitim çalışmalarında sık kullanılan araştırma türleri. Turan, S. (Ed). Eğitimde Araştırma Yöntemleri içinde (ss. 49-78). Nobel Kitabevi.

Keskin, K., \& Baştuğ, M. (2013). Okuma çalışmalarında tanılama ve yönlendirme: Program-tabanlı ölçmenin uygulaması. Ë̆itim ve Öğretim Araştırmaları Dergisi, 2(1), 264-273.

Kuruoğlu, G., \& Şen, N. (2018). Okuma güçlüğü yaşayan ortaokul öğrencilerin yaptıkları okuma hatalarının incelenmesi. Eğitim Kuram ve Uygulama Araştırmaları Dergisi, 4(2), 101-110.

Leslie, L., \& Caldwell, J. (2006). Qualitative reading inventory-4 (4th ed.). Pearson Education Inc.

Ohler, J. (2013). Digital storytelling in the classroom. New media pathways to literacy, learning, and creativity (2nd ed.). Sage Publications.

Patton, M. Q. (2002). Qualitative research and evaluation methods (3rd Ed.). Sage Publications Inc. 
Pedró, F. (2006). The new millennium learners: Challenging our views on ICT and learning. Inter-American Development Bank.

Savaş, S., \& Karataş, S. (2019). Z kuşağı öğrencisini tanımak. Kıral, E., Babaoğlan Çelik, E. \& Çilek, A. (Ed). Ĕ̆itim Araştırmaları içinde (ss. 227-240). Eğitim Yöneticileri ve Uzmanları Derneği Yayınları.

Seçkin, Ş. (2012). Okuma güçlüğü olan ve olmayan ilköğretim öğrencilerinin okuma akıcılıkları. [Yayımlanmamış yüksek lisans tezi]. Ankara Üniversitesi.

Sever, S. (2011). Türkçe ögretimi ve tam öğrenme. Anı Yayıncılık.

Sidekli, S. (2010). Eylem araştırması: ilköğretim dördüncü sınıf öğrencilerinin okuma ve anlama güçlüklerinin giderilmesi. Türklük Bilimi Araştırmaları, 27, 563-580.

Smart, D., Prior, M., Sanson, A., \& Oberklaid, F. (2001). Children with reading difficulties: A six-year follow-up from early primary school to secondary school. Australian Journal of Psychology, 53(1), 45-53.

Uzuner, Y., Kırcaali İftar, G., \& Karasu, P. (2005). Comparing the effects of various procedures on reconstruction of narratives according to story grammer of a youth with hearing loss. Reading Matrix, 5(2), 15-27.

Williams, J. P. (2005). Instruction in reading comprehension for primary-grade students: A focus on text structure. The Journal of Special Education, 39(1), 6-18.

Yangın, S. \& Sidekli, S. (2006). Okuma güçlüğü yasayan öğrencilerin kelime tanıma becerilerinin geliştirilmesine yönelik bir uygulama. Muğla Üniversitesi Sosyal Bilimler Enstitüsü Dergisi, 16.

Yıldırım, K., Turan, S., \& Bebek, N. (2012). Akıcı okumayı geliştirme dersi: Farklı bir dil ve sosyokültürel kontekstte etkililiği. Uluslararası Avrasya Sosyal Bilimler Dergisi, 3(9), 40-58.

Yılmaz, M. (2006). İlköğretim 3. sınıf ögrencilerinin sesli okuma hatalarını düzeltmede ve okuduğunu anlama becerilerini geliştirmede tekrarl okuma yönteminin etkisi. [Yayımlanmamış doktora tezi]. Gazi Üniversitesi.

Yılmaz, M. (2008). Kelime tekrar tekniğinin akıcı okuma becerilerini geliştirmeye etkisi. Türk Eğitim Bilimleri Dergisi, 6(2), 323-350.

Yüksel, A. (2010). Okuma güçlüğü çeken bir öğrencinin okuma becerisinin geliştirilmesine yönelik bir çalışma. Kuramsal Ĕgitimbilim, 3(1), 124-134. 


$\begin{array}{lllll}\text { A. AVŞARTUNCAY } & \text { Okuma Güçlüğü Yaşayan Ilkokul Öğrencilerinin Okuma IJONS } \\ \text { Hatalarının İncelenmesi } & \end{array}$

\section{EXTENDED ABSTRACT}

\section{An Assessment of the Reading Errors of Primary School Students with Reading Difficulties}

Reading difficulty is a learning disability that causes issues in the reading skills of a student even though they may be at a normal or gifted level. Many factors can negatively affect a student's literacy process, and one of these factors is errors made while reading aloud. The most common errors made by children with reading difficulties are substitution, insertion or subtraction, repetition, mispronunciation, hesitation, and misreading. The present study was conducted to determine whether the reading errors made by primary school fourth-grade students with reading difficulties while reading aloud differ according to various factors. The study employs the descriptive survey model, which is a quantitative research method. The study group consists of primary school students selected using an appropriate sampling method chosen from purposeful sampling methods. The data was collected from 32 primary school fourth-grade students in the Mersin city center in the 2019-2020 academic year. As the first step, students were asked to read the second and third level texts in the "Non-Formal Reading Inventory" to determine their reading level (Karasu, Girgin ve Uzuner, 2013). The students' readings were recorded and analyzed by their teachers. Based on the analyses, it was decided that the students should read third level texts for the study purposes. A "Student Information Form" was prepared as a data collection tool to obtain students' demographic information. The form included questions about the students' gender, parents' education level, reading frequency, preferred reading material, and reading environment. The narrative text chosen for students to read was "Ömer and the Pigeon", and the other text was "Atatürk's School Life", an informative text selected from the field of social studies. The data obtained in the study were analyzed using the SPSS-21 program. It was determined that the study group showed a normal distribution, and parametric tests were used in the analysis of the data. Independent groups t-test was used to determine whether the students differentiated according to their gender and their preferred reading environment. One-way analysis of variance (ANOVA) was used to reveal the differences according to the students' parents' education level, their reading frequency, and preferred reading material. A significant difference was observed between the insertion and mispronunciation errors made by primary school students with reading difficulties while reading aloud according to the gender variable. Regarding the number of students who made errors, female students made more errors than male students while reading both texts. Among the reading errors made by primary school students with reading difficulties while reading the narrative text, there was a significant difference in the hesitation error according to the reading environment variable, while there were no significant differences in the other reading errors. Regarding the number of students who made errors, students who read from print media made more errors while reading both texts than those who read on the internet. Regarding the reading errors they made while reading informative texts, there was a difference only in the insertion error according to the education level of their mothers. Students with reading difficulties whose mothers were literate made insertion errors, while those whose mothers were primary school graduates made subtraction and substitution errors, those whose mothers were secondary school graduates made substitution errors, and those whose mothers were high school graduates made pronunciation errors most frequently. Therefore, it was observed that the reading errors students made did not correlate with the education level of mothers. Similarly, it was concluded that the reading errors made by primary school students with reading difficulties while reading both narrative and informative texts did not differ according to the education level of their fathers. Students with reading difficulties whose fathers were primary school graduates made insertion errors, while those whose fathers were secondary school graduates made substitution errors, 
and those whose fathers were high school graduates made subtraction errors, and those whose fathers were university graduates made substitution errors most frequently. It was concluded that the reading errors students made also did not correlate with the education level of fathers. The study findings revealed that among the reading errors made by primary school students with reading difficulties while reading the narrative text, there is a significant difference in the mispronunciation error according to the variable of reading frequency. No significant difference was observed in other errors made by the students while reading the texts according to the reading frequency variable. It was found that the reading errors made by primary school students with reading difficulties while reading both the narrative and informative texts did not differ according to the preferred reading material variable. Students who preferred novels and stories made substitution and insertion errors, while those who preferred travel and nonfiction made mispronunciation errors, those who preferred science and research made substitution errors, and those who preferred poetry made insertion errors most frequently. It was concluded that the preferred reading materials of students with reading difficulties did not have a significant effect on the reading errors students made. Therefore, it can be said that demographic characteristics do not affect the prominence of an error type, and the frequency of errors is different. The study results point to the need for further studies to be conducted to reduce the reading errors of primary school students and to increase their fluent reading skills. Therefore, it is recommended to conduct screening studies to identify students with potential reading difficulties and to carry out prevention studies. The reading difficulties of students can be alleviated with prevention studies.

"International Journal of New Approaches in Social Studies - IJONASS" is licensed under a Creative Commons Attribution-NonCommercial-ShareAlike 4.0 International License. 